\title{
Koulutusasenteet teollisuustyössä
}

Markkinoiden muutokset sekä niitä seuraavat tuotannolliset uudistukset ovat nostaneet henkilöstön ja sen kehittämisen keskeisiksi tuotantoja kilpailutekijöiksi. Kiinnostus ja motivaatio kehittää niin itseään kuin työtäänkin ovat ominaisuuksia, joita työvoimalta yhä enemmän edellytetään. Kasvavista vaatimuksista huolimatta voi työvoiman vähäinen halukkuus nousta kuitenkin suoranaiseksi vastavoimaksi liiketoiminnan kehittämiselle. Toisaalta työntekijöiden asenteet koulutus- ja kehittämistoimintaan ovat monin tavoin sidoksissa työpaikoilla toimimisen ehtoihin.

Seuraavan esityksen tarkoituksena on tuoda esiin eräitä keskeisiä näkökulmia teollisuustyön ja työntekijöiden koulutusasenteiden välisiin suhteisiin sekä niihin kytkeytyviin osittain ristiriitaisiinkin tendensseihin.

Nykyisellään lähes puolet palkansaajista osallistuu vuosittain työnantajan järjestämään henkilöstökoulutukseen (Tilastokeskus 1993a). Koulutuksen volyymin kasvu erityisesti 80-luvun jälkipuoliskolla on myös yksi osoitus henkilöstövoimavaran lisääntyneestä merkityksestä. Erot osallistumisen määrissä ovat kuitenkin edelleen suuret. Niin Suomessa kuin muissakin teollisuusmaissa saadut tulokset osoittavat varsin yhdensuuntaisesti, kuinka koulutukseen osallistuminen on yhteydessä $\mathrm{mm}$. asianosaisten työtehtäviin, asemaan yrityksen hierarkias- sa, pohjakoulutukseen, ikään, sukupuoleen (esim. Berton ym. 1991; Klemm ym. 1990 ja Sundin 1987). Henkilöstökoulutuksen osalta tämä osallistumisrakenteiden eriytyminen on tyypillisesti haluttu nähdä osoituksena eroista koulutusmahdollisuuksissa - ei niinkään kysymyksenä halukkuudesta osallistua tähän koulutukseen.

Työelämän viimeaikaisina kehityssuuntina ovat olleet työvoimalle asetetut lisääntyneet vaatimukset niin oman ammatillisen pätevyytensä kuin työtehtäviensäkin kehittämiseen. Vastuun laajentuminen edellyttää työvoimalta entistä vahvempaa sitoutumista työsuhteeseen, joten on ymmärrettävää, että sitouttamisesta on tullut merkittävä koulutuspoliittinen tavoite yrityksissä.

Työsuhteeseen sitoutuminen määrittää olennaisella tavalla myös työntekijöiden koulutusasenteita (esim. Noe \& Schmitt 1986). Kaikki työntekijät eivät kuitenkaan ole halukkaita sitoutumaan vaatimuksiltaan yhä enemmän edellyttäviin työtehtäviin. Epäillä myös sopii, onko heitä niihin syytä pakottaakaan. Mitalin kääntöpuolella häämöttää kuitenkin uhka syrjäytymisestä tai ainakin lisääntyvästä polarisaatiosta työelämän tarjoamien kehittymismahdollisuuksien suhteen.

Työntekijöiden koulutusasenteita koskevissa tarkasteluissa on perinteisesti haluttu korostaa asenteiden yksilöllisyyttä. Epäilemättä tällä näkökulmalla on myös oikeutuksensa, mutta rajautuminen pelkästään yksilöpsykologisiin ja yksilöiden sosiaaliseen asemaan liittyvien tekijöiden tarkasteluun on henkilöstökoulutuksen osalta riittämätön. Henkilöstökoulutuksen erityisluonteeseen nimittäin kuuluu, että yksilölli- 
set tavoitteet ovat aina alisteisessa asemassa organisaatiotason tavoitteisiin nähden. Vähätellä ei sovi myöskään työnantajan direktio-oikeuteen perustuvaa vallankäyttöä myös henkilöstön kehittämiseen liittyvissä kysymyksissä. Työn tarjoamat mahdollisuudet ja työpaikalla toimimisen ehdot määrittävät mitä suurimmassa määrin työvoiman koulutus- ja kehittämishalukkuutta. Näin yksilöllisyyskin suodattuu henkilöstökoulutuksessa viime kädessä aina työpaikalla toimimisen rakenteellisten ehtojen kautta.

Yksityinen liike-elämä on monesti kyvytön ja halutonkin järjestämään työvoimalleen riittävästi koulutusta - jopa yrityksen omien pitemmän aikavälin etujen vastaisesti (Streeck 1989). Tämä on saanut monet kirjoittajat peräänkuuluttamaan yhteiskunnalta aktiivisempaa ja vastuullisempaa panosta myös henkilöstökoulutuksen organisointiin (esim. Rubenson 1991). Seuraavassa esityksessä näkökulma on kuitenkin rajattu työnantajan järjestämään henkilöstökoulutukseen, so. ensisijaisesti työnantajan kustantamaan ja työajalla annettuun koulutukseen.

\section{Koulutusmahdollisuuksien rajat}

Työnantajien näkökulmasta yrityksissä järjestettävän koulutuksen yksi keskeinen ongelma on ollut työntekijöiden vähäinen kiinnostus (Juhela 1993). Työntekijöiden käsityksen mukaan henkilöstökoulutukseen osallistumista on kuitenkin rajoittanut ensisijaisesti tosiasiallisten mahdollisuuksien puute - eivät niinkään heidän omat asenteensa. Esimerkiksi Tilastokeskuksen kokoaman tutkimusaineiston (nk. AKU 1990-aineisto) mukaan yli puolet ( 54 prosenttia) teollisuustyöntekijöistä arvioi koulutusmahdollisuutensa nykyisessä työpaikassaan huonoiksi ja vain joka kymmenes näkee mahdollisuutensa hyviksi.

Täysin merkityksettömiä eivät työntekijöiden omat asenteetkaan tosin ole, sillä em. aineiston mukaan neljäsosa teollisuustyöntekijöistä ei ole kiinnostunut koulutuksesta ja viidesosa katsoo, ettei koulutuksesta ole hyötyä. Jos koulutushalukkuuden osoittimena pidetään puolestaan koettuja koulutustarpeita, niin mitenkään yle- tön ei halukkuus tästä näkökulmasta näyttäisi olevan, sillä em. tutkimusaineiston mukaan vain hieman runsas kolmannes (35 prosenttia) teollisuustyöntekijöistä katsoo nykyisellään olevansa lisäkoulutuksen tarpeessa. Ja tarvetta kokevat vähiten juuri ne, joilla on koulutukseenkin heikoimmat mahdollisuudet.

Eri intressiosapuolten näkemyseroista huolimatta näyttää siltä, ettei kysymys työvoiman koulutusasenteista ole täysin ongelmaton työelämän kehittämisessä. Edellä esitetty antaa toisaalta aihetta myös epäilyyn, että työntekijöiden vähäinen kiinnostus koulutukseen olisi paljolti "pihlajanmarjojen happamuudella", mahdollisuuksien puutteella selitettävissä.

\section{Sen saa mitä tarjoaa}

Työntekijöiden koulutusasenteita tarkastelleessa tutkimuksessaan ovat Larsson ym. (1986) päätyneet tuloksiin, joiden mukaan erityisesti peruskoulutusta vailla oleva työvoima ei juurikaan koe koulutustarvetta ja toisaalta heidän suhtautumisensa koulutukseen on perin välineellinen. Tässä katsannossa koulutusasenteita muokkaavan ajattelun perusta on siis olemassa olevissa työtehtävissä. Kun työtehtävät eivät koulutusta edellytä, niin ei sitä myöskään kaivata.

Mutta ovatko kielteiset koulutusasenteet lopulta työtehtävien luonteella selitettävissä? Näiden vaikutus asenteisiin on toki ilmeinen ja edellä mainittu noidankehä pysyy sulkeutuneena niin kauan kuin työtehtävät säilyvät entisellään. Työnantajan näkökulmasta mahdolliset ongelmat työntekijöiden koulutusasenteissa nousevat kuitenkin esiin vasta sitten, kun tuotantoa pitää muuttaa ja kehittää. Tällöin ei työntekijöiden kielteisten koulutusasenteiden ongelma olekaan enää yksistään työtehtävien luonteella perusteltavissa.

Käyttökelpoisen analogian tähän pulmaan tarjoaa Willisin (1984) tutkimus työväenluokan poikien koulunvastaisesta kulttuurista. Siirtyessään koulun penkiltä palkkatyöhön työntekijät siirtävät työelämään juuri sen saman elementin vastustuksen, jota he koulumaailmasta lähtivät 
"pakoon", nimittäin oppimisen. Uusien asioiden oppiminen ja varsinkin teoreettisen tiedon opiskelu on heidän näkökulmastaan käytännölle vierasta ellei suorastaan halveksuttavaa. Tällä ajattelullaan he samalla kuitenkin sinetöivät oman kohtalonsa sisällöiltään köyhiin ja arvostukseltaan vähäisiin työtehtäviin, jotka eivät erityisemmin tarjoa näkymiä paremmasta. Vastustamalla työelämässä juuri sitä, jota he ovat vastustaneet jo ennen työelämään siirtymistä, synnyttää myös illusorisen kuvan työmarkkinoilla vapaasti liikkuvasta työntekijästä. Hänelle riittää, että työstä maksetaan palkkaa, ja nämä vaatimukset on usein suhteellisen helposti täytettävissä.

Edellä kuvattu toimintatapa pätee niin kauan kuin palkka on riittävä motiivi työlle. Asenteiden uusintaminen edellyttää taas sitä, että työmarkkinoilla on sille vastinkappale. Jos yrityksellä on tarjottavanaan vain ikävystyttäviä työtehtäviä vailla näkymiä paremmasta, niin yritys ei myöskään voi olla erityisen valikoiva työvoiman rekrytoinnissaan. Yrityksen on tyydyttävä siihen, mitä on jäljellä, kun paremman tarjouksen tehneet ovat kuorineet kerman työmarkkinoilta (Windolf 1986). Koulutetun työvoiman vieroksunta "lattiatason ideaalityöntekijää" rekrytoitaessa (ks. Silvennoinen \& Pirilä 1992) vain syventää mainittua ongelmaa. Tällä toiminnallaan työnantaja luo itse itselleen oman noidankehänsä, jossa vähäinen koulutushalukkuus on kietoutunut työvoiman rekrytointiongelmaan sekä korkeaan vaihtuvuuteen.

\section{Syrjäytymisen uhka}

Myös määrällisesti joustava työvoimareservi voi työnantajan kannalta olla tarkoituksenmukainen semminkin, jos paineet tuotannollisiin uudistuksiin rajoittuvat tai halutaan rajata vain pienimuotoisiin muutoksiin. Mutta jos näin ei ole, ovat ongelmatkin jo helpommin käsillä.

Tuotannollisten uudelleenjärjestelyjen hankaloituminen on luonnollisesti päällimmäisenä näistä ongelmista, mutta perin suurella vakavuudella työnantaja suhtautuu myös riskiin "tuhlata" rajallisia koulutusresursseja "vääriin" kohderyhmiin. Tavoiteltu oppiminen katsotaan mahdolliseksi vain koulutukseen erikseen mo- tivoituneille, joten tehokkuusvaatimuksiin perustuen kannattaa koulutusta antaa vain niille, joilla on, tai pikemminkin tulkitaan olevan, riittävä motivaatio ja oppimiskyky. Staudtin (1989) mukaan saattaa virheellisin perustein valittujen henkilöiden mukanaolo koulutuksessa heikentää myös muiden osallistujien oppimista sekä vähentää koulutuksen arvostusta niin yksilö- kuin työyhteisötasollakin.

Edellisen perusteella on myös ymmärrettävää, että oma-aloitteisuus, koulutushalukkuus ja motivaatio ovat koulutettavien valikointikriteereistä tärkeimpiä (Seyd 1984, 110-113). Kiinnostus omaan ammatilliseen kehittymiseen on helposti tulkittavissa myös osoitukseksi kiinnostuksesta omaa työtä ja sen kehittämistä kohtaan. Tällöin jo entuudestaan rajallisiksi koetut koulutusmahdollisuudet ovatkin tosiasiallisesti tarjolla vain niille, jotka ovat tavalla tai toisella kyenneet osoittamaan koulutukseen riittävästi tai mahdollisesti riittävimmin halukkuutta.

Koulutushalukkuuden ja koulutuksen valikointivaikutusten keskinäisellä vuorovaikutuksella on taipumus vahvistaa itse itseään. Tarjoutuvien mahdollisuuksien myötä myös motivaatio kasvaa ja päinvastoin. Näyttää myös siltä, että työelämän tarjoamia tulevaisuuden näköaloja jaettaessa on koulutus- ja kehittymishalukkuudesta tulossa entistä painavampi peruste (esim. Lawler \& Ledford 1992 ja Townley 1989).

Koulutushalukkuuden perustalta tehdyssä jaossa ydintyövoimaan ja periferisemmässä asemassa olevaan aputyövoimaan on työsuhdeturvalla tärkeä sija. Jos se on uhattuna, vähenee myös työhön liittyvä kehittymishalukkuus olennaisesti (Brown ym. 1993). Kehittämishalukkuus edellyttää työsuhteiden pysyvyyttä, mutta koulutusmahdollisuuksien tavoin myös työsuhdeturva on tarjolla vain kehittymishaluisimmille.

Työelämän viimeaikaiset muutospaineet sekä vapaasti liikuteltavan työvoimareservin tarpeettomuus ovat entistä laajamittaisemmin johtaneet "jyvien erotteluun akanoista" heidän kehittymishalukkuutensa mukaan. On myös varsin luultavaa, että kun yritys joutuu työn vähenemisen vuoksi lomauttamaan tai irtisanomaan henkilöstöään, niin ainakaan ensimmäisten joukossa eivät ole ne, joiden koulutukseen yritys on 
investoinut runsaimmin. Tarjoutuvat koulutusmahdollisuudet ovat tässäkin mielessä varsin herkkä anturi työsuhteiden pysyvyydelle luomalla jatkuvuuden tunnetta sekä vahvistamalla työntekijöiden käsitystä siitä, että yritys kantaa huolta työvoimastaan.

\section{Työelämän tarjoamat mahdollisuudet}

Usein esitetty väite on, että työntekijöiden suhtautuminen koulutukseen olisi leimallisen välineellistä. Epäilemättä nämä tavoitteet ovat myös aina eriasteisesti mukana, mutta yksipuolisen dominoivaksi ei välineellisyyttä siltikään voida väittää (Juhela 1993, 216-217; ks. myös Tilastokeskus 1993b, 38-40).

Asenteiden välineellisyydestä taas seuraa, että työntekijöiden koulutushalukkuus on riippuvainen tarjolla olevista "porkkanoista", jolloin myös kiinnostuksen vähäisyys olisi porkkanoiden puutteella selitettävissä.

Toki edellä puheena ollut työsuhdeturvakin voi osaltaan täyttää välineellisyyden kriteerit, mutta sen luonne on pikemminkin keppi kuin porkkana. Tästä syystä olisikin kysyttävä, kuinka perusteltuja ovat työntekijöiden koulutukselle asettamat välineelliset odotukset myös "positiivisessa" suunnassa.
Koulutukseen osallistuminen ansiotason kohoamisen toivossa edellyttää, että hankitut lisäpätevyydet tunnustetaan myös palkkauksellisesti. Nykyiset palkkausjärjestelmät perustuvat kuitenkin lähinnä työsuoritteisiin tai työtehtäviin, jolloin koulutus voi korkeintaan tukea siirtymistä paremmin palkattuihin työtehtäviin.

Jos työntekijöiden tulevaisuudenperspektiivejä tarkastellaan nimenomaan nykyisen työpaikan sisällä avautuvina mahdollisuuksina, niin jokseenkin vähäisiltä nämä mahdollisuudet kuitenkin näyttävät (taulukko 1). Työpaikan sisäinen organisaatiorakenne ja -kulttuuri tai yrityksen henkilöstöstrategia asettaa jo sellaisenaan rajat etenemismahdollisuuksille niin vertikaalisesti kuin horisontaalisestikin. Vaativammat työtehtävät, joihin niihinkään eivät siirtymismahdollisuudet ole erityisen hyvät, koetaan edelleen horisontaalisina siirtyminä ja vertikaaliseen nousuun ei työpaikan sisällä juuri mahdollisuuksia ole. Näitä mahdollisuuksia ei työpaikalla annettu lisäkoulutuskaan paremmiksi muuta (vrt. Nordhaug 1989).

Sikäli kun uralla eteneminen on yhteydessä koulutukseen, on se mahdollista vain oman työn ulkopuolella ja muodollista pätevyyttä lisäävän koulutuksen kautta. Koulutukseen on kuitenkin omaehtoisesti hakeuduttava ilman takeita siitä, että sen jälkeen olisivat uusia pätevyyksiä vastaavat työtehtävät odottamassa. Täs-

Taulukko 1. Teollisuustyöntekijöiden käsitykset nykyisen työn tarjoamista mahdollisuuksista (\%)

Siirtyä työtehtävästä
toiseen omalla
työpaikalla

Erittäin paljon

Melko paljon

Jonkin verran

Ei juuri lainkaan

Ei osaa sanoa

Yhteensä

$(\mathrm{N}=555)$

Lähde: AKU 1990-aineisto
Siirtyä työkokemuksen karttuessa entistä vaativampiin työtehtäviin
Edetä ammattiuralla ylöspäin 
tä huolimatta on erityisesti angloamerikkalaisessa kirjallisuudessa haluttu korostaa uralla etenemistä myös henkilöstökoulutukseen osallistumisen keskeisenä motiivina.

Itse asiassa yksilöllisen urakehityksen tukeminen voi johtaa koulutushalukkuuden kannalta jopa kielteisiin vaikutuksiin. "Uraputken" avautuminen sisältää jo sellaisenaan tietynasteisen lupauksen kehittymismahdollisuuksista, mutta jos näitä ei syystä tai toisesta kyetäkään lunastamaan, saattaa se aiheuttaa pettymyksiä ja turhautumista. Työyhteisötasolla voi seurauksena olla puolestaan sisäisen integraation heikentyminen, kun kehittymismahdollisuudet havaitaan avautuneen vain harvoille ja valituille, mikä äärimmillään saattaa johtaa nk. kruununprinssi-efektiin (ks. Nadler \& Nadler 1989, 64-69).

\section{Noidankehän murtaminen}

Larsson ja kumppanit tarjosivat aiemmin edellä mainitussa tutkimuksessaan työntekijöiden kielteisten koulutusasenteiden ja niiden instrumentaalisuuden välisen ongelman ratkaisuksi, että kyseisten henkilöiden koulutusta koskevia asenteita tulisi muuttaa ja että välineellisilläkin tavoitteilla tulisi olla katetta. Mutta mitä nämä ratkaisut voisivat sitten sisältää?

Jälkimmäisten osalta tuskin ajan oloon riittää (kuten monin paikoin edelleen näyttäisi olevan käytäntönä), että koulutukseen motivoidaan esimerkiksi "tarjoilupuolesta huolehtimalla" tai järjestämällä "paljon puhuttu saunailta" koulutuksen yhteyteen. Yksilöllisen uralla etenemisen edistämiseen ja tukemiseen on puolestaan sisäänrakennettuna ajatus työtehtävien rakenteen staattisuudesta ja siten myös mahdollisuuksien asteittaisesta kaventumisesta. Kehittämisen kohde ei siis voi perustellusti olla uralla etenemisen tukeminenkaan. Ratkaisun avaimia on sen sijaan etsittävä työtehtävien kehittämisestä. Tavoitteena ei tällöin olisikaan siirtyä esimerkiksi suunnittelutehtäviin, vaan laajentaa työtehtävät myös suunnittelua sisältäviksi.

Henkilöstön kehittämisen yksi viime aikojen keskeisimpiä haasteita on ollut pyrkimys työ- voiman joustavuuteen. Monitaitoisuuden kehittäminen latentiksi potentiaaliksi ei kuitenkaan pitkän päälle jaksa innostaa, jos työn muotoilu ei tarjoa mahdollisuuksia uusien pätevyyksien soveltamiseen käytännössä. Toisaalta taas työnantajakaan ei ole kiinnostunut järjestämään työntekijöilleen monitaitoisuutta kehittävää koulutusta, jos nämä eivät vastavuoroisesti osoita halukkuutta ottaa näitä pätevyyksiä käyttöön.

Työn organisatorisia uudelleenjärjestelyjä ei kuitenkaan ole ehkäissyt niinkään työntekijöiden haluttomuus kehittää ammattitaitojensa laaja-alaisuutta tai ottaa sitä käyttöön, vaan esimerkiksi palkkausjärjestelmien jäykkyys (Mahnkopf 1992) taikka muutosvastarinta niiden henkilöstöryhmien taholta, jotka kokevat työvoiman joustavuuden lisäämisen uhaksi omalle asemalleen (Drexel 1985 ja Hirsch-Kreinsen \& Wolf 1987).

\section{Koulutusasenteiden uudelleenarviointia}

Henkilöstökoulutuksen ensisijainen "välinearvo" on työtehtävien ja työn organisoinnin kehittämisessä. Tällöin on myös ymmärrettävää, ettei itsensä kehittäminen useinkaan kiinnosta koulutuksen välityksellä sellaisenaan, jos työt eivät samanaikaisesti muutu. Silloin kun henkilöstön kehittäminen ja koulutus mielletään työn kehittämisenä, saa osallistumishalukkuuskin jo toisen sisällön.

Edellisestä seuraa, ettei koulutushalukkuus ole täsmälleen sama asia kuin kehittämis- tai kehittymishalukkuus. Onstenk (1992) on jopa todennut teollisuustyöntekijöille olevan yleisemminkin ominaista suhtautua passiivisesti koulutukseen mutta aktiivisemmin uusien tietojen ja taitojen oppimiseen. Passiivisen koulutusasenteen takaa voi siis löytyä aktiivinen uusiin tietoihin ja taitoihin kohdistuva ja työtehtävien kehittämiseen suuntautunut oppimisasenne, mikä ei välttämättä kanavoidu varsinkaan iäkkäämmissä työntekijäryhmissä erityisenä halukkuutena koulutukseen osallistumiseen. Tähän näyttäisi viittaavan myös se havainto, että kun koulutus- tai kehittämistoimiin on ryhdytty, niin työntekijöiden osallistumisaktiivisuus ei enää 
saakaan samaa kritiikkiä osakseen, vaan asia on pikemminkin päinvastoin (Juhela 1993, 217-218).

Työntekijöiden nuiva suhtautuminen koulutukseen on usein yksinkertaisesti seurausta vähäisistä aiemmista kokemuksista sekä sen aiheuttamasta epävarmuudesta ja huolesta koulutuksessa menestymisestä. Esimerkiksi AKU 1990-aineiston mukaan vähintään 10 vuotta työelämässä olleista on edelleenkin kolmasosa sellaisia, jotka eivät ole työhistoriansa aikana osallistuneet työnantajan järjestämään henkilöstökoulutukseen.

Vaikka nämä pelot olisivatkin kokemuksellisesti aitoja, niin paras lääke niihin on kokemusten kartuttaminen eli koulutus- ja kehittymismahdollisuuksien avaaminen. Kääntäen tämä tulee esiin myös siinä, että henkilöstökoulutuksen selvästi tärkeimmiksi yksilötasoisiksi vaikutuksiksi mielletään tekijät, jotka lisäävät asianosaisten opiskelu- ja oppimisvalmiutta (Nordhaug 1989).

Kaikkein voimakkaimmin työntekijöiden koulutushalukkuutta vähentävät käytännössä osallistumisen ehdot. Koulutus työajan ulkopuolella tai omalla kustannuksella ei useinkaan kiinnosta; sikäli kun osallistuminen on näillä ehdoin ylipäätään mahdollistakaan. Kyseisillä ehdoilla voi kuitenkin olla tulevaisuuden kannalta polarisoiva vaikutus. On nimittäin varsin luontevaa ajatella, että ne, jotka ovat valmiit uhraamaan varojaan ja vapaa-aikaansa opiskeluun, ovat siihen myös motivoituneimpia. Epärealistista sen sijaan on ajatella, kuten joillakin työnantajilla on taipumus tehdä, että motivaatiota voitaisiin ikään kuin lisätä siirtämällä koulutus työajan ulkopuolelle tai ainakin osittain työntekijöiden itsensä kustannettavaksi.

Asenteet muuttuvat myönteisemmiksi ja halukkuutta voidaan ylläpitää vain, kun kehittymiseen tarjoutuu tosiasialliset mahdollisuudet. Tämä taas edellyttää taakseen yritysjohdon tuen - ei vain koulutusmahdollisuuksien avaamisen merkityksessä, vaan myös esimerkinantajana. Jos yritysjohto ei koulutusta arvosta, niin paljoa ei voitane odottaa työntekijöiden asenteiltakaan. Tutkimuksissa on jopa todettu, että yritysten koulutusasioista vastaavilla henkilöillä on
- jos mahdollista - työntekijöitäkin kapeampi ja välineellisempi näkemys työntekijöiden koulutuksesta (Larsson ym. 1986, 125-132).

\section{Työntekijöiden vaikutus mahdollisuudet ja osallistumisvalmiudet}

Työntekijöiden kielteisten koulutusasenteiden takaa voi joissain tapauksissa löytyä myös muut kuin koulutus- tai kehittämistoimintaan liittyvät asenteet. Se, mitä vastustetaan tai mikä aiheuttaa epävarmuutta, saattaa varsinaisesti olla esimerkiksi uuden tuotantoteknologian käyttöönotto tai varsinkin se tapa, jolla uutta tuotantoteknologiaa otetaan käyttöön, mutta johon liittyvä vastarinta kanavoituu nimenomaan koulutuksen vastustamisena.

Muutosvastarinnan nimikkeellä tunnetun ongelman koulutuksellinen ratkaisu saattaa johtaa tällöin siihen, ettei koulutuksella enää pyritäkään kyseisten uudistusten edellyttämien uusien pätevyyksien kehittämiseen, vaan perimmäiseksi tarkoitukseksi jääkin uuden tuotantoteknologian hyväksytyksi tekeminen sekä yleisemmin työvoiman asenteiden muokkaaminen tuotannollisille uudistuksille myönteisiksi (Pilnei 1985).

Erityisesti asenteisiin, ideologisiin kvalifikaatioihin, liittyvässä koulutuksessa voi työntekijöiden motivointi osoittautua hankalaksi, kun toiminta heidän taholtaan mielletään enemmän indoktrinaatioksi tai manipulaatioksi kuin kehittämistoiminnaksi. Työntekijöiden kielteiset koulutusasenteet voivat yleisemminkin kohdistua nimenomaan tarjottuun koulutukseen ja siinä koettuihin puutteisiin - ei niinkään koulutusja kehittämistoimintaan sinänsä.

Edellä esitettyjen näkökulmien yhteinen nimittäjä on työntekijöiden vähäiset tai vähäisiksi kokemat mahdollisuudet osallistua koulutusta koskevaan päätöksentekoon sekä siitä aiheutuvan "yhteisesti jaetun vision" puute (ks. Senge 1990). Ongelman ydin paikantuu tällöin siihen, kenen koulutuskonseptista onkaan kyse. Yksipuolisesti työnantajan intresseistä lähtevä koulutus kykenee vain harvoin ylittämään sen mo- 
tivaatiokynnyksen, mikä vähäiselläkin työntekijöiden osallistumismahdollisuuksien lisäämisellä olisi mahdollista saavuttaa.

Työntekijöiden osallistumis- ja vaikutusmahdollisuudet on jo pitkään tunnettu työelämän kehittämishankkeiden itsestään selvänä peruslähtökohtana. Tästä huolimatta näyttää asian esiinnostaminen olevan aina ajankohtaista, sillä kokonaisuutena teollisuustyöntekijöiden mahdollisuudet vaikuttaa niin koulutusta kuin yleisemminkin työtehtävien kehittämistä koskevaan päätöksentekoon ovat edelleenkin vähäiset (Juhela 1993, 73-86).

Koulutus- ja kehittymismahdollisuuksien avaaminen sekä näiden kytkeminen työtehtävien kehittämiseen ovat varmastikin työntekijöiden koulutushalukkuuden perusedellytyksiä, mutteivat sittenkään riittäviä. On nimittäin samanaikaisesti huolehdittava myös siitä, että työntekijöillä on tosiasialliset mahdollisuudet osallistua niin koulutusta kuin työn muotoiluakin koskevaan suunnitteluun ja päätöksentekoon. Työntekijöiden vähäisten vaikutusmahdollisuuksien ongelma on tuskin ratkaistavissa yksin lainsäädännöllisin keinoin, vaikkeivat ne tässä suhteessa olekaan täysin vailla merkitystä (ks. Gill 1993).

Työelämän yhdeksi viime aikojen kehityssuunnaksi on toisaalta haluttu nähdä organisaatiorakenteiden desentralisoituminen sekä hierarkioiden madaltuminen. Tämän seurauksena työntekijöiltä vaaditaan entistä laajamittaisempaa vastuunottoa sekä osallistumista erilaiseen yritystoimintaa koskevaan päätöksentekoon. Yrityksen päätöksentekoprosesseihin osallistuminen edellyttää kuitenkin valmiuksia tähän toimintaan. Asianmukaisten pätevyyksien puutteessa voi osallistuminen osoittautua yhtä lailla turhauttavaksi kuin tehottomaksikin (Heller 1993). Tästä syystä on nimenomaan organisatorisesti varmistettava, että työntekijät myös kykenevät vastaamaan näihin haasteisiin.

Työntekijöiden päätöksentekokapasiteetin tukeminen ja vahvistaminen niin osallistamalla kuin koulutuksellisestikin ovat työelämän keskeisiä tulevaisuuden haasteita - varsinkin jos todella halutaan nähdä henkilöstö yrityksen tärkeimpänä voimavarana. Yritysten kilpailukyky on myös entistä riippuvaisempi siitä, kuinka tehokkaita oppimisympäristöjä ne pystyvät rakentamaan. Ja näiden oppimisympäristöjen rakentamistyö ei ole vain "jokamiehen" oikeus vaan kaikkien velvollisuus.

\section{LÄHTEET}

Berton, F. \& Podevin, G. \& Verdier, E. 1991. Continuing Vocational Training in France. CEREQ: Training \& Employment 2, 1-4.

Brown, C. \& Reich, M. \& Stern, D. 1993. Becoming a highperformance work organization: the role of security, employee involvement and training. The International Journal of Human Resource Management 4, 2, 247-275.

Drexel, I. 1985. Wann werden Arbeitskräfte gegen Rationalisierung aktiv? Thesen zum Zusammenhang zwischen subjektiven Aktionspotentialen und Erwerbsverlaufsmustern. Teoksessa Fricke, W. \& Schuchardt, W. (Hrsg.): Innovatorische Qualifikationen - eine Chance gewerkschaftlicher Arbeitspolitik. Verlag Neue Gesellschaft: Bonn.

Gill, C. 1993. Technological change and participation in work organization: recent results from a European Community survey. The International Journal of Human Resource Management 4, 2, 325-348.

Heller, F. 1993. The under-utilization of human resources in industrial relations theory and practice. The International Journal of Human Resource Management 4, 3, 631-644.

Hirsch-Kreinsen, H. \& Wolf, H. 1987. Neue Produktionstechniken und Arbeitsorganisation. Intressen und Strategien betrieblicher Akteure. Soziale Welt 1987, 38, 2, 181-196.

Juhela, A. 1993. Henkilöstökoulutus ja henkilöstön kehittäminen jatkuvan koulutuksen mahdollisuuksina. Lisensiaatintutkimus. Tampereen yliopiston kasvatustieteiden laitos. Tampere.

Klemm, K. u.a. 1990. Bildungsgesamtplan '90. Ein Rahmen für Reformen. Juventa Verlag: Weinheim \& München.

Larsson, S. \& Alexandersson, C. \& Helmstad, G. \& Thång, P.O. 1986. Arbetsupplevelse och utbildningssyn hos icke facklärda. Acta Universitatis Gothoburgensis. Göteborg studies in educational sciences 57. Göteborg.

Lawler, E. \& Ledford, G. 1992. A skill-based approach to human resource management. European Management Journal 10, 4, 383-391.

Mahnkopf, B. 1992. The 'skill-oriented' strategies of German trade unions: Their impact on efficiency and equality objectives. British Journal of Industrial Relations 30, 1, 61-81. 
Nadler, L. \& Nadler, Z. 1989. Developing Human Resources. Jossey-Bass Publishers: San Francisco.

Noe, R.A. \& Schmitt, N. 1986. The influence of trainees' attitudes on training effectiveness: Test of a model. Personnel Psychology 39, 497-523.

Nordhaug, O. 1989. Reward functions of personnel training. Human Relations 42, 5, 373-388.

Onstenk, J. 1992. Training for employees with low educational qualifications. ECER:in konferenssissa Twentessä 22.-25.6.1992 jaettu moniste.

Pilnei, M. 1985. Thesen zur Entwicklung der betrieblicher Weiterbildung im Zeitalter der Neuen Technologien. Zeitschrift für Berufs- und Wirtschaftspädagogik 81, 6, 537-549.

Rubenson, K. 1991. Aikuiskoulutuksen kehittäminen markkinavoimien ohjattavaksi vai tavoitteiseen politiikkaan? Aikuiskasvatus 11, 2, 66-75.

Senge, P. 1990. The fifth discipline: The art and practice of the learning organization. Doubleday/Currancy: New York.

Seyd, W. 1984. Betriebliche Weiterbildung. Daten - Tendenzen - Probleme. Leuchtturm-Verlag: Alsbach.

Silvennoinen, H. \& Pirilä, A. 1992. Lattiatason ideaalityöntekijä. Työn vaatimusten, työntekijän ominaisuuksien ja rekrytointistrategioiden yhteensovittuminen. Työpoliittinen Aikakauskirja 4, 13-25.
Staudt, E. 1989. Unternehmensplanung und Personalentwicklung - Defizite, Widersprüche und Lösungsansätze. Mitteilungen aus der Arbeitsmarkt- und Berufsforschung $22,3,374-387$.

Streeck, W. 1989. Skills and the limits of neo-liberalism: The enterprise of the future as a place of learning. Work, Employment \& Society 3, 1, 89-104.

Sundin, S. 1987. Personalutbildningens volym och inriktning - rikstrenden och ett regionalt exempel. Teoksessa Abrahamsson, K. (Red.): Vuxenutbildningens nya uppdrag. Forum V. Skolöverstyrelsen, Rapporter R 87:28. Stockholm.

Tilastokeskus 1993a. Henkilöstökoulutus 1991. Koulutus 1993:1. Helsinki.

Tilastokeskus 1993b. (Simpanen, M.) Aikuiskoulutustutkimus 1990. Aikuiskoulutus ja työelämä. Tutkimuksia 201. Helsinki.

Townley, B. 1989. Selection and appraisal: reconstituting 'social relations'? Teoksessa Storey, J. (Ed.): New perspectives on human resource Management. Routledge: London and New York.

Willis, P. 1984. Koulun penkiltä palkkatyöhön. Vastapaino: Tampere.

Windolf, P. 1986. Recruitment, selection, and internal labour markets in Britain and Germany. Organization Studies 7, 2, 235-254. 